\title{
Treatment of Copper Contaminated Municipal Wastewater by Using UASB Reactor and Sand-Chemically Carbonized Rubber Wood Sawdust Column
}

\author{
Swarup Biswas ${ }^{1}$ and Umesh Mishra ${ }^{2}$ \\ ${ }^{1}$ Department of Environmental Engineering, NIT Agartala, Tripura 799046, India \\ ${ }^{2}$ Department of Civil Engineering, NIT Agartala, Tripura 799046, India \\ Correspondence should be addressed to Swarup Biswas; swarup.biswas85@gmail.com
}

Received 15 August 2015; Revised 20 December 2015; Accepted 28 December 2015

Academic Editor: Yan Zhou

Copyright (C) 2016 S. Biswas and U. Mishra. This is an open access article distributed under the Creative Commons Attribution License, which permits unrestricted use, distribution, and reproduction in any medium, provided the original work is properly cited.

\begin{abstract}
The performance of a laboratory scale upflow anaerobic sludge blanket (UASB) reactor and its posttreatment unit of sandchemically carbonized rubber wood sawdust (CCRWSD) column system for the treatment of a metal contaminated municipal wastewater was investigated. Copper ion contaminated municipal wastewater was introduced to a laboratory scale UASB reactor and the effluent from UASB reactor was then followed by treatment with sand-CCRWSD column system. The laboratory scale UASB reactor and column system were observed for a period of 121 days. After the posttreatment column the average removal of monitoring parameters such as copper ion concentration $(91.37 \%)$, biochemical oxygen demand $\left(\mathrm{BOD}_{\mathrm{T}}\right)(93.98 \%)$, chemical oxygen demand (COD) (95.59\%), total suspended solid (TSS) $(95.98 \%)$, ammonia $(80.68 \%)$, nitrite (79.71\%), nitrate (71.16\%), phosphorous (44.77\%), total coliform (TC) (99.9\%), and fecal coliform (FC) (99.9\%) was measured. The characterization of the chemically carbonized rubber wood sawdust was done by scanning electron microscope (SEM), X-ray fluorescence spectrum (XRF), and Fourier transforms infrared spectroscopy (FTIR). Overall the system was found to be an efficient and economical process for the treatment of copper contaminated municipal wastewater.
\end{abstract}

\section{Introduction}

The increasing population and water consumption have forced to concentrate on the reuse of wastewater. As the municipal wastewater is easy to treat and is easily available it has always been a good source for wastewater remediation. Nowadays rapid industrialization is contaminating the municipal wastewater stream by discharging toxic metal like copper which is harmful for human and other living beings. According to Environmental Protection Agency (EPA) the copper discharge limit is $1.00 \mathrm{mg} / \mathrm{L}$. The municipal wastewater itself contains suspended solid, nutrients, and organic and inorganic pollutants which are harmful for human and environment $[1,2]$.

In current research trend, anaerobic treatment is observed as a good choice for wastewater treatment because it does not require oxygen which results in no energy requirement and in return it releases energy in the form of methane. As effluent generated by upflow anaerobic sludge blanket (UASB) reactor does not meet the maximum permissible level of sewage discharge standards of most developing countries including India, the posttreatment became necessary [3]. Various posttreatment options for UASB reactor effluent have been used such as anaerobic filters [4], dissolved air flotation [5], rotating biological contactor [6], overland flow process [7], down-flow hanging sponge [8], trickling filter [9], activated sludge process [10], and constructed wetlands [11]. Although most of these options have some limitations such as high operating and maintenance cost and excessive land requirement.

Slow sand filters are mainly used for the treatment of surface waters [12] as well as for the posttreatment of secondary effluents [13]. Various researchers investigated the feasibility of slow sand filters as a posttreatment unit at laboratory and pilot scale using different hydraulic loading and sand size. They suggested that slow sand filters are capable 
of removing biochemical oxygen demand (BOD), suspended solids (SS), turbidity, and total coliforms (TC) up to $86 \%$, $68 \%$, and $88 \%$ and over $99 \%$, respectively $[13,14]$. Due to its simplicity and less manpower requirement, sand filters are considered to be an economical technique.

Second convenient option for the treatment of wastewaters is the use of activated carbon (AC) as adsorbent. Adsorption provides an attractive alternative treatment because of its low cost and easy availability. AC was able to remove both organic and inorganic pollutants from wastewater [15]. In biological processes $\mathrm{AC}$ serves as a carrier for biofilm attachment for the treatment of wastewater [16]. Therefore, in biological activated carbon (BAC), the biological activity inside the AC system can facilitate simultaneous adsorption and biodegradation which increases the service life of AC filters [17, 18]. Due to the high adsorption and biodegradation capabilities of BAC filters, they are considered a good substitute for sand filters for removing not only suspended solids but also the organics more efficiently.

In the present study the copper contaminated municipal wastewater is treated by a laboratory scale UASB and sand-chemically carbonized rubber wood sawdust (sandCCRWSD). The study is focused on development of a laboratory scale secondary and posttreatment system which can give better efficiency for the treatment of copper ion contaminated municipal wastewater.

\section{Materials and Methods}

2.1. Preparation of $\mathrm{Cu}$ Contaminated Municipal Wastewater. The municipal wastewater was collected weekly at the day time from the drainages of Agartala, Tripura, India, and stored in a container. The copper contaminated $(40 \mathrm{mg} / \mathrm{L})$ municipal wastewater was prepared by adding the appropriate amount of external $\mathrm{CuCl}_{2}$ (Merck India) salt to municipal wastewater in another batch reactor and it was used as UASB influent. The effluent coming from the UASB reactor was treated by sand-CCRWSD column system. The UASB and sand-CCRWSD column system was monitored for a period of 121 days.

2.2. Preparation of the Adsorbents. The sand was collected from the nearby area of the Howrah River, Tripura, India. The sand was washed several times with deionized water and sieved for the desire particle size of $0.25-1 \mathrm{~mm}$. The rubber wood sawdust was collected from rubber wood processing industry, Nagechera, Tripura, India, and it was utilized to prepare CCRWSD. Concentrated sulphuric acid (98\%) and concentrated nitric acid (98\%) were purchased from Merck India. The rubber wood sawdust $(10 \mathrm{gm})$ was introduced to $11 \mathrm{~mL}(98 \% \mathrm{~m} / \mathrm{m})$ concentrated $\mathrm{H}_{2} \mathrm{SO}_{4}$ and stands for 10 minutes to make it carbonized. Then carbonized slurry was added to concentrated $\mathrm{HNO}_{3}(6.6 \mathrm{~mL}, 65 \% \mathrm{~m} / \mathrm{m})$. The slurry material was heated at $150^{\circ} \mathrm{C}$ for 24 hours. The CCRWSD was then thoroughly washed with deionized water to remove the acid and dried at oven. Finally screening was used to get the desired particle size $(0.5-1 \mathrm{~mm})$.
2.3. Analysis and Characterization. The copper ion concentrations in wastewater were analyzed by using the atomic absorption spectrophotometer (Perkin Elmer Model AAS 700). The surface of the adsorbent was analyzed by scanning electron microscope (SEM). X-ray fluorescence (XRF) spectrum (Model Phillips PW2404, PANAlytical) was utilized to observe the percentage of the elements present in the adsorbent. Fourier transforms infrared spectroscopy (FTIR) (Buker 3000 Hyperion, Germany) spectra were used to determine the functional groups of the adsorbent. Total phosphorus, ammonia, nitrite, nitrate, chemical oxygen demand (COD), biochemical oxygen demand $\left(\mathrm{BOD}_{\mathrm{T}}\right)$, total suspended solid (TSS), total coliforms (TC), and fecal coliforms (FC) of the aqueous solution were determined as per standard methods (APHA) [19].

2.4. Experimental Setup. The experimental system of the UASB and sand-CCRWSD is represented in Figure 1. The identical $34.68 \mathrm{~L}$ bench scale UASB reactor was run for the period of 121 days. At the batch scale UASB reactors with corresponding length, width, and depth of $17 \mathrm{~cm}, 120 \mathrm{~cm}$, and $17 \mathrm{~cm}$, respectively, were installed with hydraulic retention time (HRT) of $16 \mathrm{hrs}$ (optimizing in different HRT). Copper contaminated municipal wastewater was used as influent for the UASB reactor. The $150 \mathrm{~cm}$ sand-CCRWSD column with a diameter of $5 \mathrm{~cm}$ was utilized as a posttreatment unit. The posttreatment column consists of two different parts where in lower portion $50 \mathrm{~cm}$ was filled with CCRWSD and in upper portion sand was used for $50 \mathrm{~cm}$ height. The $0.1 \mathrm{~cm}$ thick glass wool was used in between the sand column and CCRWSD column to prevent their mixing of the sand and CCRWSD. In the bottom of the column the $0.1 \mathrm{~cm}$ thick glass wool was used to avoid the loss of the adsorbent. The column was operated in down-flow mode at a maximum influent flow rate of $9.4 \mathrm{~mL} / \mathrm{min}$ (optimizing the follow rate) at room temperature. Backwashing was made in every two weeks or when the head loss in the filter reached a critical value.

\section{Results and Discussion}

3.1. Characterization of the CCRWSD. The functional groups of the CCRWSD are determined by using FTIR spectra which shows (Figure 2) the presence of $\mathrm{C}=\mathrm{O}$ group $\left(1708.58 \mathrm{~cm}^{-1}\right)$, -COO ${ }^{-}$group $\left(1612.56 \mathrm{~cm}^{-1}\right)$, and C-O group $\left(1164.34 \mathrm{~cm}^{-1}\right)$. The shifting of the peak shown in Figure 3 is due to the adsorption of the copper ion and the other impurities. SEM images show the surface structure of the CCRWSD (Figures 4(a) and 4(b)) before and after filtration of UASB effluent. The XRF analysis (Table 1) shows the presence of calcium, carbon, sulphur, and oxygen in the CCRWSD and after posttreatment the presence of the copper ion is observed which gives a strong evidence of copper ion adsorption onto CCRWSD.

3.2. Removal of Copper Ion. The concentrations of copper ion after UASB and posttreatment were summarized in Table 2. It was found that copper ion concentration was gradually decreased by sand treatment and CCRWSD treatment which was shown in Figure 5. The average removal of $73.28 \%$ is 


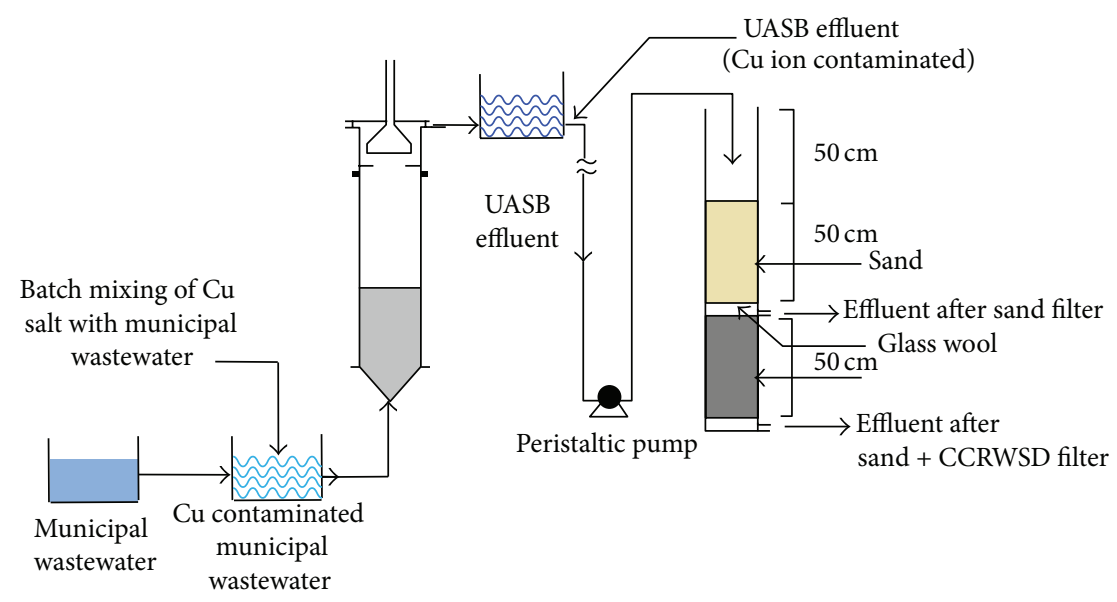

FIGURE 1: Schematic diagram of laboratory scale experimental setup.

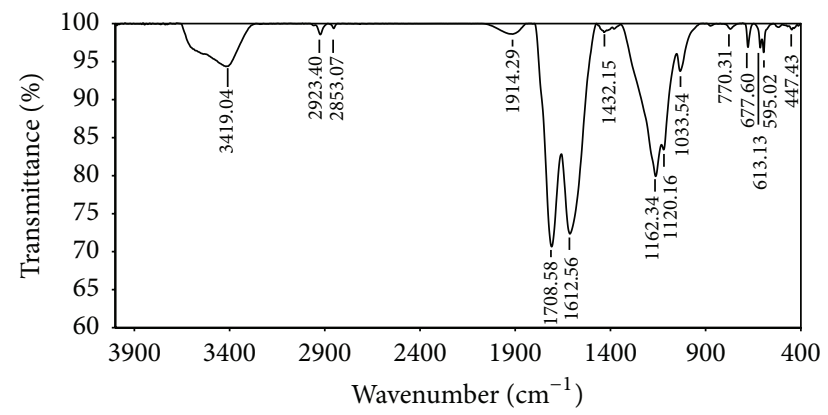

FIGURE 2: FTIR spectra of CCRWSD.

TABLE 1: XRF analysis on the CCRWSD before and after treatment of UASB effluent.

\begin{tabular}{lcc}
\hline Elements (\%) & CCRWSD & Lead-loaded CCRWSD \\
\hline $\mathrm{O}$ & 31.24 & 21.54 \\
$\mathrm{C}$ & 61.41 & 59.21 \\
$\mathrm{Na}$ & 0.020 & 0.002 \\
$\mathrm{Ca}$ & 0.427 & 0.14 \\
$\mathrm{Cu}$ & - & 2.47 \\
$\mathrm{~S}$ & 0.643 & 0.081 \\
$\mathrm{Cl}$ & 0.190 & 0.078 \\
\hline
\end{tabular}

found after sand treatment and after CCRWSD treatment the average removal was increased up to $91.37 \%$. In adsorption process copper ion get defused into the hole of the adsorbents. Due to biological activation the adsorption process worked for a long time which increased the efficiency of the posttreatment unit.

3.3. Removal of $B O D_{T}$. The characteristics of the municipal wastewater, UASB reactor effluent, and treated wastewater were given in Table 2. The $\mathrm{BOD}_{\mathrm{T}}$ of UASB reactor effluents and posttreatment effluents were decreased as compared to the untreated municipal wastewater as shown in Figure 6. The average $\mathrm{BOD}_{\mathrm{T}}$ removal after UASB treatment was $83.60 \%$. The average $\mathrm{BOD}_{\mathrm{T}}$ concentration after sand filtration was

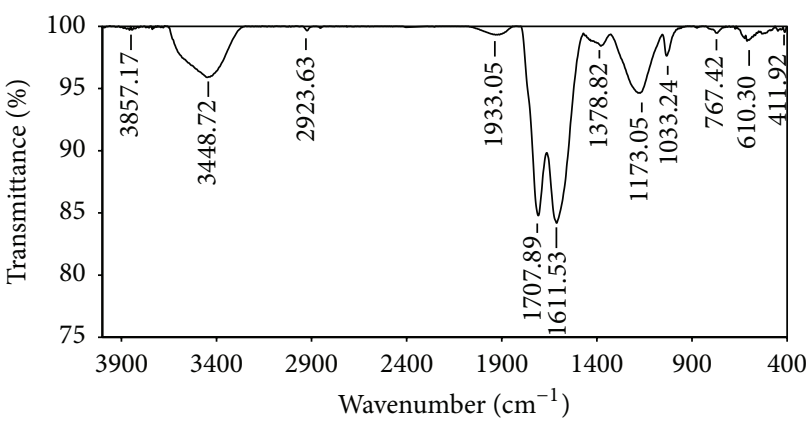

FIGURE 3: FTIR spectra of CCRWSD after filtration of UASB effluent.

$6.38 \mathrm{mg} / \mathrm{L}$ whereas after CCRWSD filter average concentration was $2.36 \mathrm{mg} / \mathrm{L}$. Though UASB effluent had low oxygen concentration, in the upper part of the column UASB effluent came in contact with atmospheric air which helped aerobic microorganisms for the reduction of $\mathrm{BOD}_{\mathrm{T}}$ in the system. Similar results were reported by Devi et al. [24] where AC, made up of Avacado Peels, was utilized for the removal of $\mathrm{BOD}$ from wastewater. The removal efficiency of $\mathrm{BOD}_{\mathrm{T}}$ in present study is similar to the results (86\%) reported by $\mathrm{Al}$ Adham [25]. On the other hand BOD removal was totally dependent on the biodegradation of the organics. In primary days, $\mathrm{BOD}_{\mathrm{T}}$ removal of the UASB effluent was low and increased after 2-3 days when the sand and CCRWSD became biologically active. The system was operated for a long period and for the entire period the sand and CCRWSD remain biologically active which contributed a good $\mathrm{BOD}_{\mathrm{T}}$ removal efficiency.

3.4. Removal of COD. The COD concentration of the municipal wastewater, UASB effluent, and posttreatment effluent was summarized in Table 2 . The COD was removed efficiently by the UASB treatment and the average removal of $57.82 \%$ was achieved. On the other hand, average COD concentrations after CCRWSD filtration were $15.94 \mathrm{mg} / \mathrm{L}$ with average percentage removal of $95.59 \%$ during the study period. The results showed that the UASB treatment and posttreatment 
TABLE 2: Characteristics of UASB and posttreatment unit effluents.

\begin{tabular}{|c|c|c|c|c|c|c|c|}
\hline \multirow{2}{*}{ Parameters } & \multirow{2}{*}{$\begin{array}{c}\text { Municipal wastewater } \\
\text { Range }\end{array}$} & \multicolumn{2}{|c|}{ UASB effluent } & \multicolumn{2}{|c|}{ After sand filtration } & \multicolumn{2}{|c|}{ After CCRWSD filtration } \\
\hline & & Range & $\%$ removal & Range & $\%$ removal & Range & $\%$ removal \\
\hline Copper ion $(\mathrm{mg} / \mathrm{L})$ & $37.84-41.35$ & $19.27-21.15$ & $47.39-52.87$ & $8.29-13.24$ & $66.14-79.94$ & $1.54-6.72$ & $83.74-96.12$ \\
\hline $\mathrm{COD}(\mathrm{mg} / \mathrm{L})$ & $310.4-420.1$ & $125.1-167.5$ & $46.67-64.46$ & $26.3-64.7$ & $80.75-93.59$ & $10.2-27.4$ & $92.06-97.46$ \\
\hline $\mathrm{BOD}_{\mathrm{T}}(\mathrm{mg} / \mathrm{L})$ & $29.35-49.14$ & $10.68-22.23$ & $33.06-74.66$ & $4.22-9.45$ & $71.93-90.07$ & $1.4-3.4$ & $89.60-97.06$ \\
\hline TSS (mg/L) & $172-240$ & $154-225$ & $2.03-21.82$ & $25-94$ & $52.04-89.58$ & $3.7-11.6$ & $94.08-98.46$ \\
\hline TDS $(\mathrm{g} / \mathrm{L})$ & $1.86-2.01$ & $1.70-1.91$ & $1.59-13.06$ & $0.35-1.89$ & $0.48-81.57$ & $0.32-1.87$ & $1.40-83.45$ \\
\hline Ammonia (mg/L) & $10.24-13.65$ & $11.73-17.74$ & nil & $2.34-6.43$ & $40.96-82.76$ & $0.71-4.82$ & $57.60-95.00$ \\
\hline Nitrite $(\mathrm{mg} / \mathrm{L})$ & $11.64-20.14$ & $12.51-21.89$ & nil & $4.25-9.65$ & $23.05-75.37$ & $1.94-5.37$ & $65.85-89.97$ \\
\hline Nitrate $(\mathrm{mg} / \mathrm{L})$ & $12.3-18.36$ & $19.82-28.47$ & nil & $4.67-12.56$ & $5.50-59.41$ & $3.27-7.38$ & $57.46-79.60$ \\
\hline Phosphate (mg/L) & $5.86-12.34$ & $21.64-29.84$ & nil & $6.8-17.4$ & nil & $2.16-7.04$ & $9.15-77.07$ \\
\hline $\begin{array}{l}\text { Total coliform } \\
\text { (MPN/100 mL) }\end{array}$ & $1.20 \times 10^{11}-1.20 \times 10^{14}$ & $7.5 \times 10^{4}-9.3 \times 10^{6}$ & 99.99 & $15-1.2 \times 10^{4}$ & 99.99 & $4-4.3 \times 10^{2}$ & 99.99 \\
\hline $\begin{array}{l}\text { Fecal coliform } \\
(\mathrm{MPN} / 100 \mathrm{~mL})\end{array}$ & $2.30 \times 10^{8}-2.40 \times 10^{13}$ & $6.4 \times 10^{4}-9.3 \times 10^{6}$ & 99.99 & $14-1.1 \times 10^{4}$ & 99.99 & $3-3.9 E \times 10^{2}$ & 99.99 \\
\hline
\end{tabular}

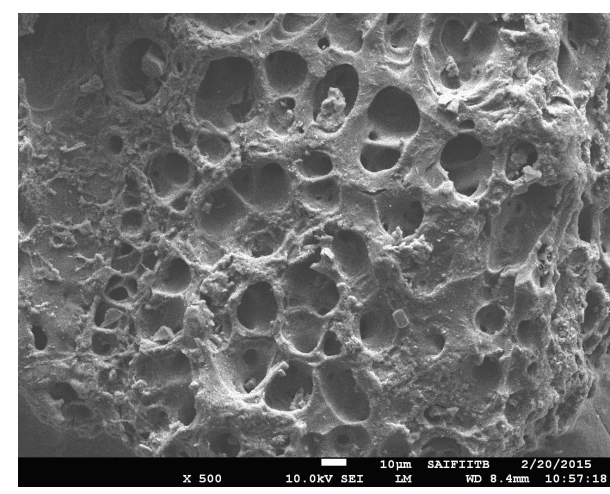

(a)

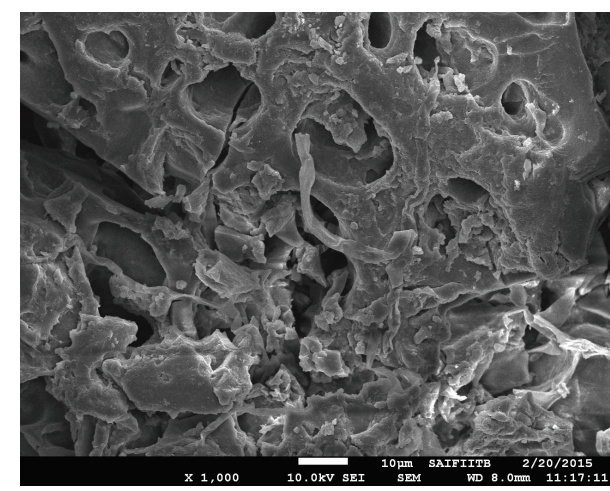

(b)

FIGURE 4: (a) SEM image of CCRWSD; (b) SEM image of CCRWSD after filtration of UASB effluent.

column were effective for the removal of COD from municipal wastewater and were shown in Figure 7. Similar results were found by Healy et al. [26] where the performance of a stratified sand filter for the removal of COD from high-strength wastewater was studied. In literature it was observed that fly ash, brick kiln ash, and commercial activated carbons were utilized for COD remediation from domestic wastewater with removal efficiencies of $88.8 \%$ and $99 \%$ [27]. In some research works coconut coir saw dust and avocado peel carbons were also investigated for COD remediation [24, 28]. COD concentration in the UASB effluents was removed by physical, chemical, and biological processes in primary days. But after saturation, removal occurred only due to biodegradation of organics present in the UASB effluent.

3.5. Removal of TSS. The concentrations of TSS in municipal wastewater, UASB effluent, and posttreatment effluent were measured (Table 2). The removal efficiency of TSS in UASB treatment was low (average removal 8.63\%) but in posttreatment unit $64.84 \%$ (average) removal was found after sand filtration and $95.98 \%$ (average) removal was achieved after
CCRWSD filtration. Though the UASB treatment was not able to remove TSS effectively the posttreatment played a vital role to remove the TSS (Figure 8). The results agreed with the findings by Healy et al. [26] where 99\% removal of TSS was found by using sand filter. In the study the maximum TSS removal by sand filtration was significantly higher than the results reported by Al-Adham [25], that is, only $68 \%$ at a hydraulic loading of $0.16 \mathrm{~m} / \mathrm{h}$ and an effective sand size of $0.23 \mathrm{~mm}$. Present observation was similar to the results by Ellis [13] as he observed $90 \%$ removal of suspended solids.

3.6. Nitrogen Removal. The concentrations of ammonia, nitrite, and nitrate in municipal wastewater, UASB effluent, and their posttreatment unit were explained in Table $2 . \mathrm{NH}_{4}{ }^{-}$ $\mathrm{N}$ concentrations in municipal wastewater, UASB effluent, and posttreatment effluent were shown as a function of time in Figure 9. As the methane was generated in the anaerobic process the concentration of $\mathrm{NH}_{4}-\mathrm{N}$ was increased after UASB treatment. The average concentration of $\mathrm{NH}_{4}-\mathrm{N}$ in UASB effluent was $14.89 \mathrm{mg} / \mathrm{L}$ which was reduced by $65.85 \%$ by sand filtration in posttreatment unit. Similarly $80.68 \%$ 


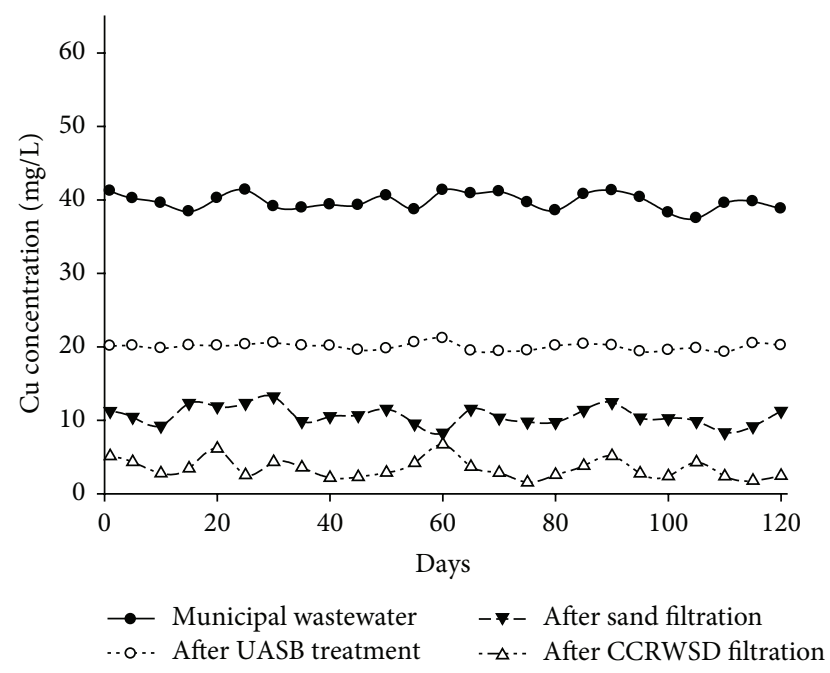

Figure 5: $\mathrm{Cu}$ ion removal.

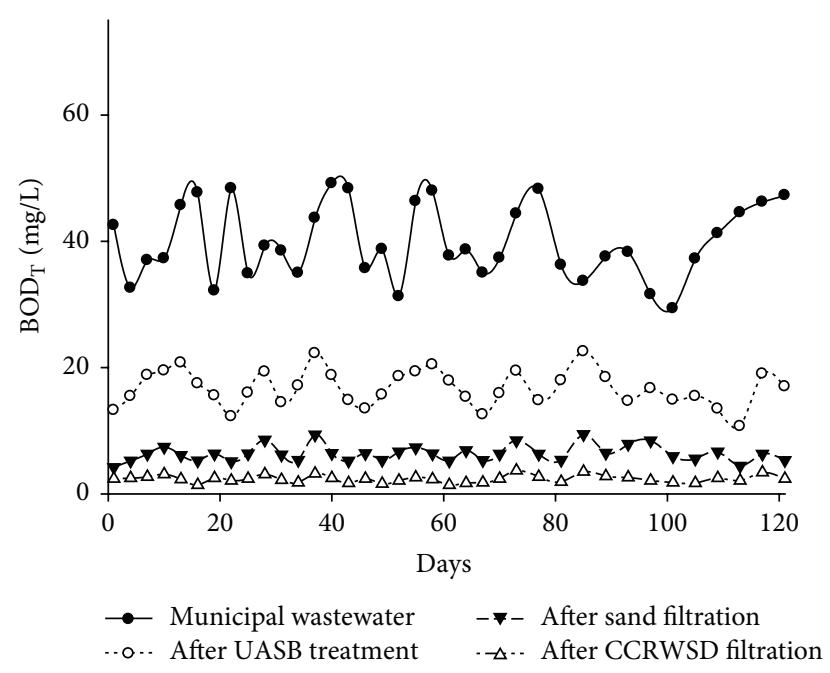

FIgURE 6: $\mathrm{BOD}_{\mathrm{T}}$ removal.

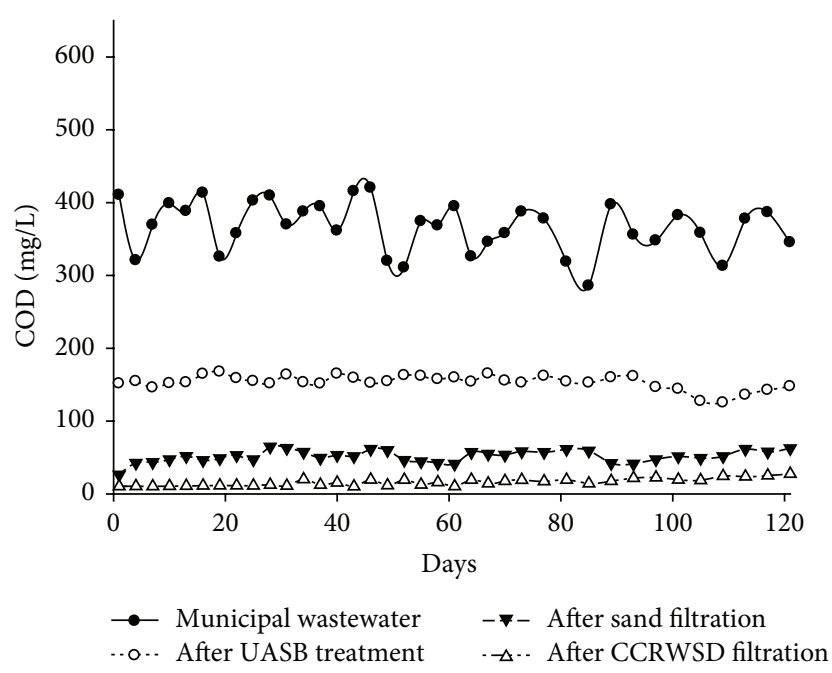

Figure 7: COD removal.

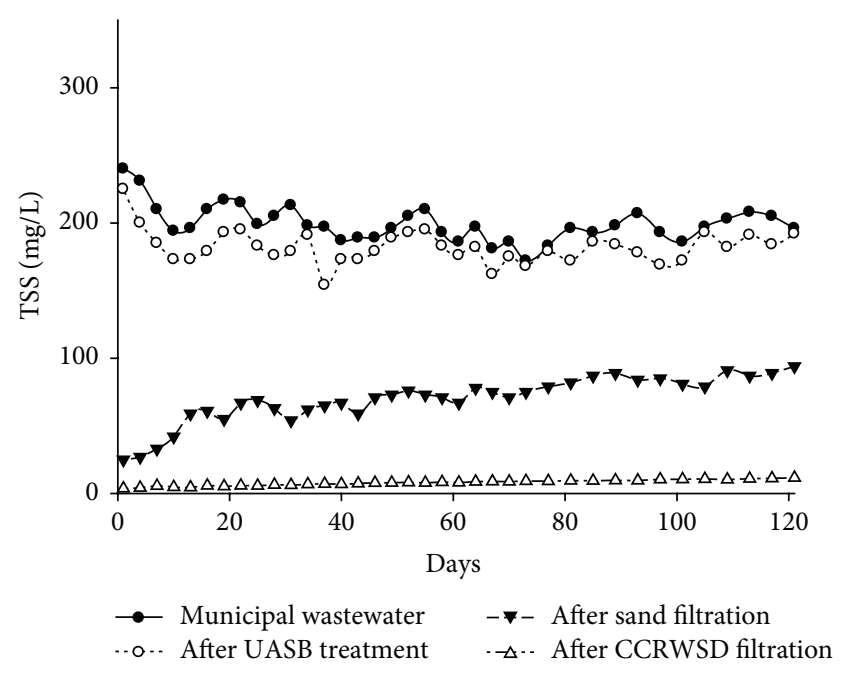

FIGURE 8: TSS removal.

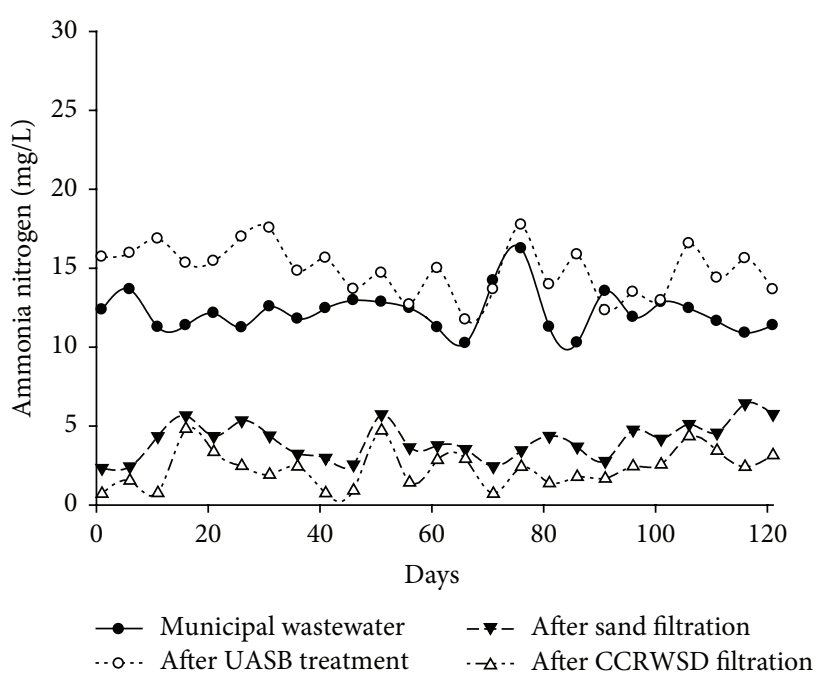

FIgURE 9: Ammonia nitrogen removal.

average removal was found after CCRWSD column during 121 days of operation.

Simultaneously the concentrations of the nitrite and nitrate in the municipal wastewater were varied from $11.64 \mathrm{mg} / \mathrm{L}$ to $20.14 \mathrm{mg} / \mathrm{L}$ and from $12.3 \mathrm{mg} / \mathrm{L}$ to $18.36 \mathrm{mg} / \mathrm{L}$ which were also increased after UASB treatment. The effect of UASB and posttreatment unit for removal of nitrite and nitrate from municipal wastewater was shown in Figures 10 and 11 . In case of nitrite average removal was $53.57 \%$ after sand filtration while after CCRWSD filtration average removal percent was $79.71 \%$. The average nitrate removal was $44.17 \%$ after sand filtration part and 71.16\% after CCRWSD filtration. During this period experiments revealed that oxygen concentration in UASB effluent was always less and therefore the environment was suitable for denitrification. In one of the previous studies [18] the authors observed 95\% nitrification efficiency in BAC columns. Lower nitrification efficiency is observed in the current study due to low dissolved oxygen concentrations. Higher $\mathrm{NH}_{4}-\mathrm{N}$ concentrations in the 


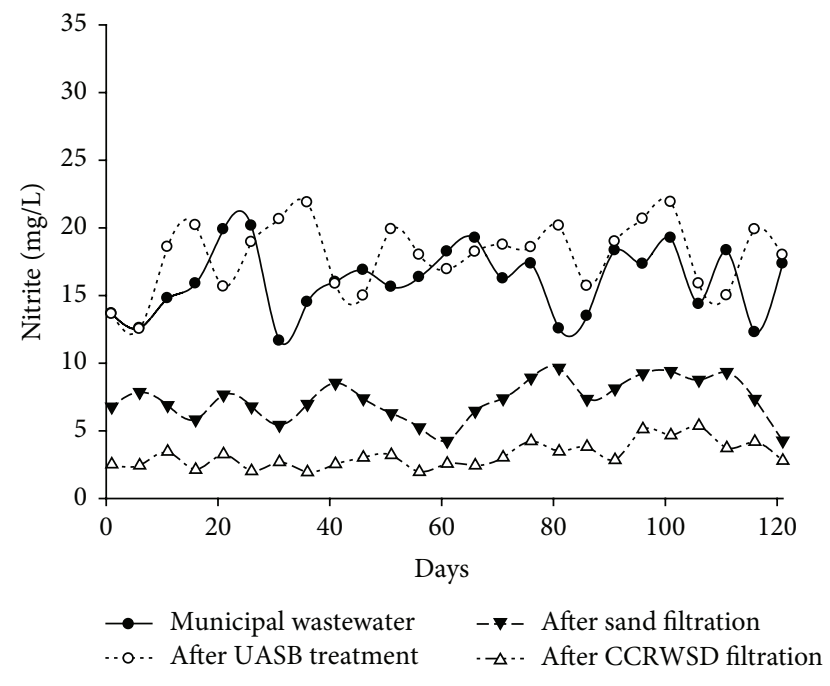

FIGURE 10: Nitrite nitrogen removal.

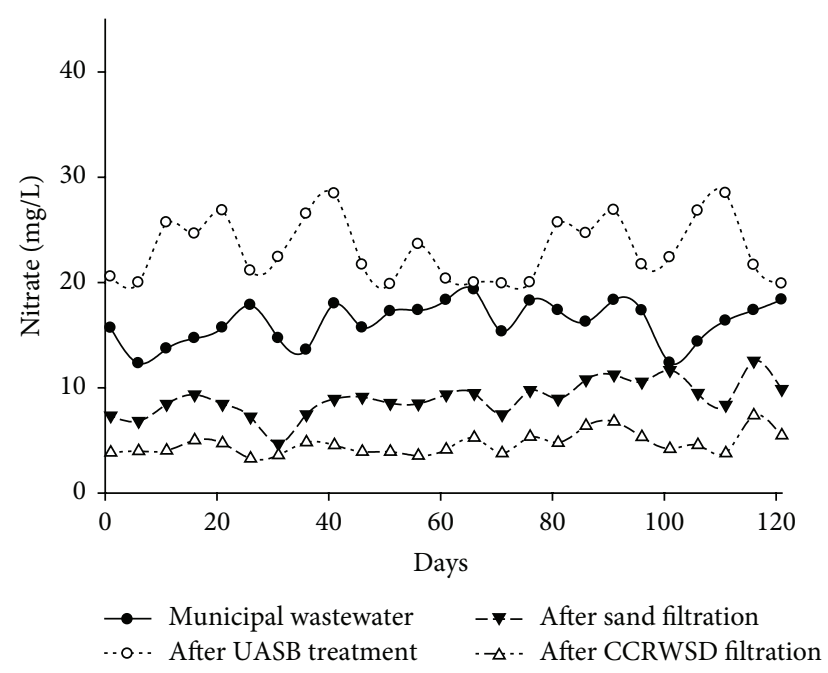

FIgURE 11: Nitrate nitrogen removal.

secondary effluent demand higher oxygen consumption for biodegradation. Organic nitrogen mostly remains in the form of $\mathrm{NH}_{4}$ which usually oxidize to $\mathrm{NO}_{2}$ and finally to a more stable form of nitrogen $\left(\mathrm{NO}_{3}\right)$. Nitrogen concentrations were effectively removed in the sand-CCRWSD system by nitrification and denitrification process. The autotrophic and heterotrophic bacteria present in the UASB effluent started nitrification from the first days of operation and reduced ammonia. Low oxygen concentration is good for denitrification [18] in UASB effluents. Therefore, biologically activated sand-CCRWSD system removed total nitrogen concentration in the form of ammonia, nitrite, and nitrate efficiently for the long period of operation.

3.7. Phosphate Removal. The concentration of phosphate in municipal wastewater varied from $5.86 \mathrm{mg} / \mathrm{L}$ to $12.34 \mathrm{mg} / \mathrm{L}$. In the anaerobic treatment concentration of phosphate in UASB effluent was increased (shown in Table 2). The average

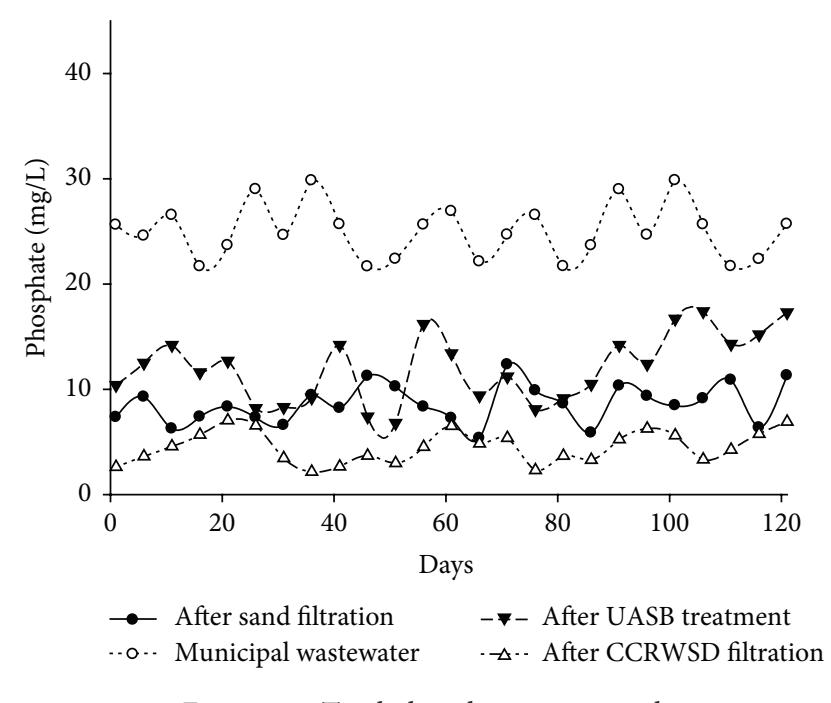

FIgURE 12: Total phosphorous removal.

$\mathrm{PO}_{4}$ concentrations in UASB effluent and after sand filtration were $25 \mathrm{mg} / \mathrm{L}$ and $12.04 \mathrm{mg} / \mathrm{L}$. After sand filtration the average removal of $4.5 \%$ was achieved whereas after CCRWSD filtration the average removal percentage was $44.77 \%$. The fate of phosphorous concentration and its percent removal after UASB, sand filtration, and CCRWSD filtration with increasing days is shown in Figure 12. In one study of sand filter total phosphorous removal was $36 \%$ to $37 \%$ which is slightly similar to the present experimental results [29]. Rodgers et al. [30] stated the $90 \%$ removal of the phosphorous by sand filtration. The decrease in the $\mathrm{PO}_{4}$ concentration could be due to the decomposition of some organic phosphorus from the wastewater by the activated sand and the activated carbon. Microorganisms present in biologically active system use phosphorous and nitrogen for their cell growth [30, 31]. The biologically activated sand-CCRWSD system had the presence of bacteria, protozoa, algae, and various microorganisms which utilized phosphorous as nutrient and decreased total phosphorous concentration from UASB effluent.

3.8. Removal of TC and FC. The concentrations of TC and FC in municipal wastewater were described in Table 2. A very good amount of removal was taking place in UASB treatment shown in Figures 13 and 14. During the study period after sand filtration TC concentrations in the effluent were $15 \mathrm{MPN} / 100 \mathrm{~mL}$ to $1.2 \times 10^{4} \mathrm{MPN} / 100 \mathrm{~mL}$ and after CCRWSD filtration they were $4 \mathrm{MPN} / 100 \mathrm{~mL}$ to $4.3 \times$ $10^{2} \mathrm{MPN} / 100 \mathrm{~mL}$. FC concentrations in the effluent after sand filtration and after CCRWSD filtration were $14 \mathrm{MPN} / 100 \mathrm{~mL}$ to $1.1 \times 10^{4} \mathrm{MPN} / 100 \mathrm{~mL}$ and $3 \mathrm{MPN} / 100 \mathrm{~mL}$ to $3.9 \times$ $10^{2} \mathrm{MPN} / 100 \mathrm{~mL}$. In case of TC and FC after posttreatment $99.99 \%$ and $99.99 \%$ removal were achieved. The removal of pathogens in the present study was significantly higher than the result by Al-Adham [25] as reported in literature. Similarly Bellamy et al. [32] reported that the average coliform removal was $97 \%$ in their study. The present study concludes that in this system almost $99.9 \%$ coliform (TC and FC) removal was achieved after 10 days and TC and FC 
TABLE 3: Comparison of UASB + sand-CCRWSD column with other treatment units.

\begin{tabular}{|c|c|c|c|c|c|c|c|}
\hline Technology & $\mathrm{COD}(\mathrm{mg} / \mathrm{L})$ & $\mathrm{BOD}(\mathrm{mg} / \mathrm{L})$ & TSS (mg/L) & $\mathrm{NH}_{4}(\mathrm{mg} / \mathrm{L})$ & $\mathrm{NO}_{3}(\mathrm{mg} / \mathrm{L})$ & Fecal coliform (MPN/100 mL) & References \\
\hline UASB + DHS & 62 & 16.5 & 17.5 & 8.8 & 6.6 & $3.8 \times 10^{4}$ & {$[10]$} \\
\hline $\mathrm{UASB}+\mathrm{AFB}$ & 61.66 & 18 & 19 & & & & {$[14]$} \\
\hline $\mathrm{UASB}+\mathrm{RBC}$ & 95 & & & 24 & 22.9 & & {$[6]$} \\
\hline UASB + shallow PP & & 27 & 26 & & & & {$[20]$} \\
\hline UASB + ozonation & 53 & 20 & 13 & & 0.94 & 84 & {$[21]$} \\
\hline $\mathrm{UASB}+\mathrm{ASP}$ & 128 & & 99 & & & & [22] \\
\hline $\mathrm{UASB}+\mathrm{AF}$ & 114 & 28 & 32 & & & & {$[4]$} \\
\hline $\begin{array}{l}\text { Inland surface water } \\
\text { standard }\end{array}$ & 250 & 30 & 100 & 50 & 50 & 10000 & {$[23]$} \\
\hline Drinking water standard & & 2 & & - & 45 & 0 & [23] \\
\hline UASB + sand-CCRWSD & 10.2 & 1.4 & 3.7 & 0.71 & 3.27 & 3 & Present study \\
\hline
\end{tabular}

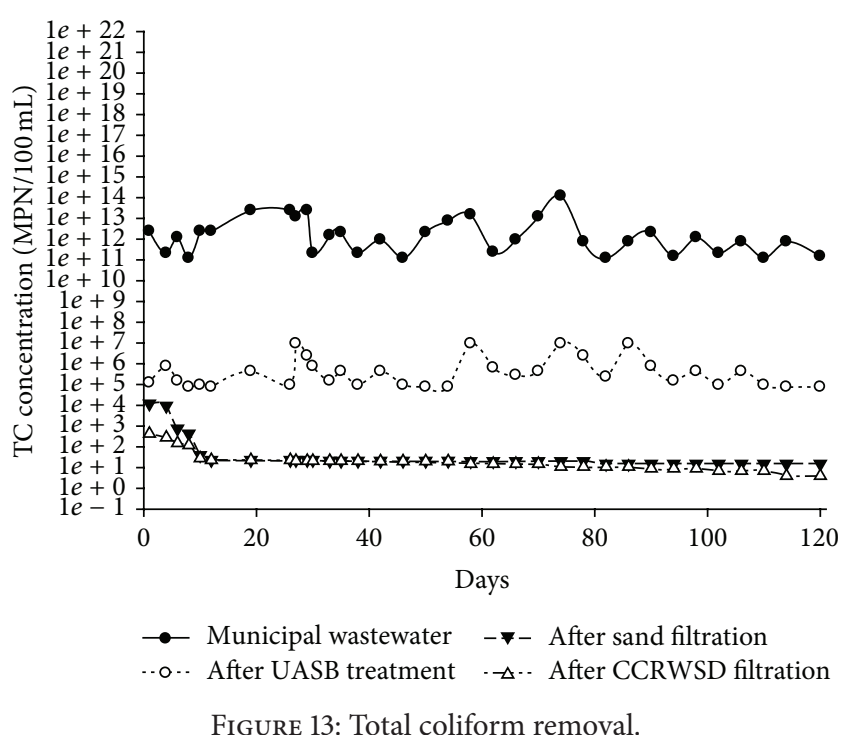

concentrations were also observed below the discharge limit as prescribed by WHO [33]. In first few days, nutrient-rich UASB effluent leads to the formation of biologically active mats which is the mixture of photosynthetic microorganism and heterotrophic bacteria referred to as "Schmutzdecke" [34]. Due to better oxygen availability the growth of biomass was high in the upper part of the filter which gave higher removal efficiency of the coliform. The maximum removal of coliforms was achieved by the sand bed and the remaining coliforms were removed by the CCRWSD.

3.9. Comparison of UASB + Sand-CCRWSD Column with Other Treatment Units. The comparison of UASB + sandCCRWSD column with the other treatment unit for the removal of contaminants is illustrated in Table 3. Comparing with the other treatment technique the system is found as the efficient technique to remove the $\mathrm{COD}, \mathrm{BOD}_{\mathrm{T}}$, ammonia, nitrate, and fecal coliform. It is observed that the sand and CCRWSD system leading to best adsorption would probably be the most suitable type for biodegradation as well.

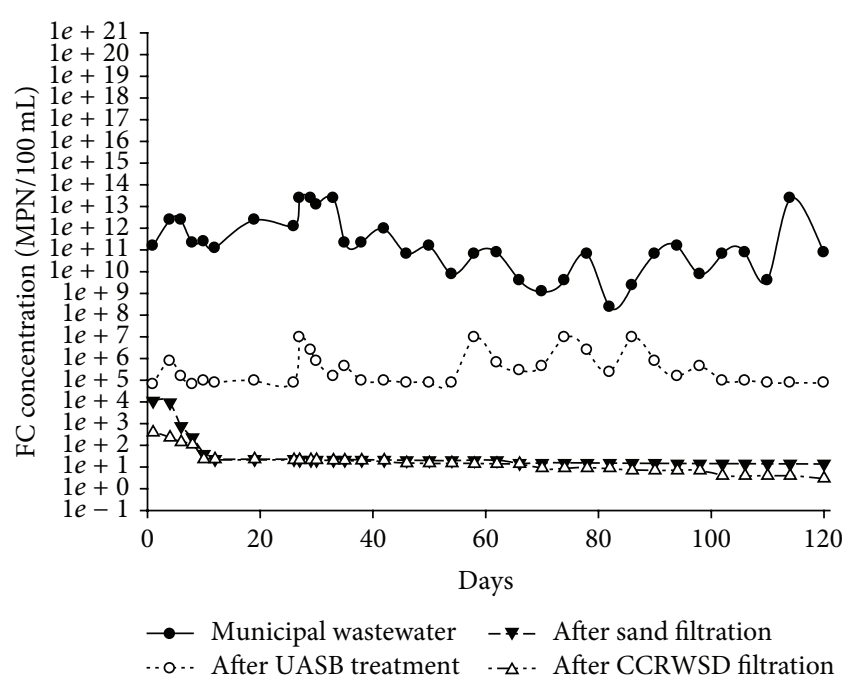

Figure 14: Fecal coliform removal.

\section{Conclusions}

This study shows that the copper contaminated municipal wastewater can be treated effectively by the combine system of UASB and sand-CCRWSD column. Simultaneously the system can efficiently remove $\mathrm{BOD}_{\mathrm{T}}$, COD, TSS, nitrogen, phosphorous, and coliforms. Therefore, the UASB and sandCCRWSD column system can lead to one of the best economical municipal wastewater treatments and can probably be considered as the most suitable type for biodegradation process.

\section{Conflict of Interests}

The authors hereby declare no conflict of interests.

\section{Acknowledgment}

The authors are thankful to the Director of National Institute of Technology Agartala for providing necessary research facilities. 


\section{References}

[1] A. Bousher, X. Shen, and R. G. J. Edyvean, "Removal of coloured organic matter by adsorption onto low-cost waste materials," Water Research, vol. 31, no. 8, pp. 2084-2092, 1997.

[2] M. Salgot, "Water reclamation, recycling and reuse: implementation issues," Desalination, vol. 218, no. 1-3, pp. 190-197, 2008.

[3] I. Machdar, Y. Sekiguchi, H. Sumino, A. Ohashi, and H. Harada, "Combination of a UASB reactor and a curtain type DHS (downflow hanging sponge) reactor as a cost-effective sewage treatment system for developing countries," Water Science and Technology, vol. 42, no. 3-4, pp. 83-88, 2000.

[4] C. A. L. Chernicharo and R. M. G. Machado, "Feasibility of the UASB/AF system for domestic sewage treatment in developing countries," Water Science and Technology, vol. 38, no. 8-9, pp. 325-332, 1998.

[5] N. T. Manjunath, I. Mehrotra, and R. P. Mathur, "Treatment of wastewater from slaughterhouse by DAF-UASB system," Water Research, vol. 34, no. 6, pp. 1930-1936, 2000.

[6] A. Tawfik, A. Klapwijk, F. El-Gohary, and G. Lettinga, "Potentials of using a rotating biological contactor (RBC) for posttreatment of anaerobically pre-treated domestic wastewater," Biochemical Engineering Journal, vol. 25, no. 1, pp. 89-98, 2005.

[7] C. A. L. Chernicharo, "Post-treatment options for the anaerobic treatment of domestic wastewater," Reviews in Environmental Science and Biotechnology, vol. 5, no. 1, pp. 73-92, 2006.

[8] M. Tandukar, A. Ohashi, and H. Harada, "Performance comparison of a pilot-scale UASB and DHS system and activated sludge process for the treatment of municipal wastewater," Water Research, vol. 41, no. 12, pp. 2697-2705, 2007.

[9] E. Awuah and K. A. Abrokwa, "Ghana Performance evaluation of the UASB sewage treatment plant at James town (Mudor)," in Proceedings of the 33rd WEDC International Conference, pp. 20-25, Accra, Ghana, 2008.

[10] A. Tawfik, F. El-Gohary, A. Ohashi, and H. Harada, "Optimization of the performance of an integrated anaerobic-aerobic system for domestic wastewater treatment," Water Science and Technology, vol. 58, no. 1, pp. 185-194, 2008.

[11] M. A. El-Khateeb, A. Z. Al-Herrawy, M. M. Kamel, and F. A. El-Gohary, "Use of wetlands as post-treatment of anaerobically treated effluent," Desalination, vol. 245, no. 1-3, pp. 50-59, 2009.

[12] G. S. Logsdon, D. G. Neden, A. M. D. Ferguson, and S. D. LaBonde, "Testing direct filtration for the treatment of highturbidity water," American Water Works Association, vol. 85, no. 12, pp. 39-46, 1993.

[13] K. V. Ellis, "Slow sand filtration as a technique for the tertiary treatment of municipal sewages," Water Research, vol. 21, no. 4, pp. 403-410, 1987.

[14] V. K. Tyagi, A. A. Khan, A. A. Kazmi, I. Mehrotra, and A. K. Chopra, "Slow sand filtration of UASB reactor effluent: a promising post treatment technique," Desalination, vol. 249, no. 2, pp. 571-576, 2009.

[15] E. A. El-Sharkawy, A. Y. Soliman, and K. M. Al-Amer, "Comparative study for the removal of methylene blue via adsorption and photocatalytic degradation," Journal of Colloid and Interface Science, vol. 310, no. 2, pp. 498-508, 2007.

[16] K. Abu-Salah, G. Shelef, D. Levanon, R. Armon, and C. G. Dosoretz, "Microbial degradation of aromatic and polyaromatic toxic compounds adsorbed on powdered activated carbon," Journal of Biotechnology, vol. 51, no. 3, pp. 265-272, 1996.
[17] G. M. Walker and L. R. Weatherley, "Biological activated carbon treatment of industrial wastewater in stirred tank reactors," Chemical Engineering Journal, vol. 75, no. 3, pp. 201-206, 1999.

[18] K. Yapsakli and F. Çeçen, "Effect of type of granular activated carbon on DOC biodegradation in biological activated carbon filters," Process Biochemistry, vol. 45, no. 3, pp. 355-362, 2010.

[19] APHA, Standard Methods for the Examination of Water and Wastewater, American Public Health Association, Washington, DC, USA, 21st edition, 2005.

[20] M. von Sperling and J. G. B. de Andrada, "Simple wastewater treatment (UASB reactor, shallow polishing ponds, coarse rock filter) allowing compliance with different reuse criteria," Water Science \& Technology, vol. 54, no. 11-12, pp. 199-205, 2006.

[21] T. M. T. Gasi, L. A. V. Amaral, C. E. M. Pacheco et al., "Ozone application for the improvement of UASB reactor effluent I. Physical-chemical and biological appraisal," Ozone: Science \& Engineering, vol. 13, no. 2, pp. 179-193, 1991.

[22] M. Von Sperling, V. H. Freire, and C. A. De Lemos Chernicharo, "Performance evaluation of a UASB-activated sludge system treating municipal wastewater," Water Science \& Technology, vol. 43, no. 11, pp. 323-328, 2001.

[23] Central Pollution Control Board (CPCB), Pollution Control Acts, Rules and Notifications Issued Thereunder, MoEF, GOI, New Delhi, India, 4th edition, 2001.

[24] R. Devi, V. Singh, and A. Kumar, "COD and BOD reduction from coffee processing wastewater using Avacado peel carbon," Bioresource Technology, vol. 99, no. 6, pp. 1853-1860, 2008.

[25] S. S. Al-Adham, Tertiary treatment of municipal sewage via slow sand filtration [M.S. thesis], King Fahd University of Petroleum and Minerals, Dhahran, Saudi Arabia, 1989.

[26] M. G. Healy, M. Rodgers, and J. Mulqueen, "Performance of a stratified sand filter in removal of chemical oxygen demand, total suspended solids and ammonia nitrogen from highstrength wastewaters," Journal of Environmental Management, vol. 83, no. 4, pp. 409-415, 2007.

[27] R. Devi and R. P. Dahiya, "Chemical oxygen demand (COD) reduction in domestic wastewater by fly ash and brick kiln ash," Water, Air, and Soil Pollution, vol. 174, no. 1-4, pp. 33-46, 2006.

[28] R. Devi, D. R. P. ahiya, and K. Gadgil, "Investigation of coconut coir carbon and sawdust based adsorbents for combined removal of COD and BOD from domestic wastewater," in Water and Environmental Management Series, pp. 1209-1218, International Water Association, London, UK, 2002.

[29] D. J. Nichols, D. C. Wolf, M. A. Gross, and E. M. Rutledge, "Renovation of septic effluent in a stratified sand filter," in Site Characterization and Design of on-Site Septic Systems, M. S. Bedinger, J. S. Fleming, and A. I. Johnson, Eds., pp. 235-247, American Society for Testing and Materials, 1997.

[30] M. Rodgers, X.-M. Zhan, and J. Prendergast, "Wastewater treatment using a vertically moving biofilm system followed by a sand filter," Process Biochemistry, vol. 40, no. 9, pp. 3132-3136, 2005.

[31] Ç. Kalkan, K. Yapsakli, B. Mertoglu, D. Tufan, and A. Saatci, "Evaluation of Biological Activated Carbon (BAC) process in wastewater treatment secondary effluent for reclamation purposes," Desalination, vol. 265, no. 1-3, pp. 266-273, 2011.

[32] W. D. Bellamy, G. P. Silverman, D. W. Hendricks, and G. S. Logsdon, "Removing Giardia cysts with slow sand filtration," Journal-American Water Works Association, vol. 77, no. 2, pp. 52-60, 1985. 
[33] M. L. Weber-Shrik and R. I. Dick, "Physical-chemical mechanisms in slow sand filters," Journal-American Water Works Association, vol. 89, no. 1, pp. 87-99, 1997.

[34] H. Sumino, M. Takahashi, T. Yamaguchi et al., "Feasibility study of a pilot-scale sewage treatment system combining an upflow anaerobic sludge blanket (UASB) and an aerated fixed bed (AFB) reactor at ambient temperature," Bioresource Technology, vol. 98, no. 1, pp. 177-182, 2007. 

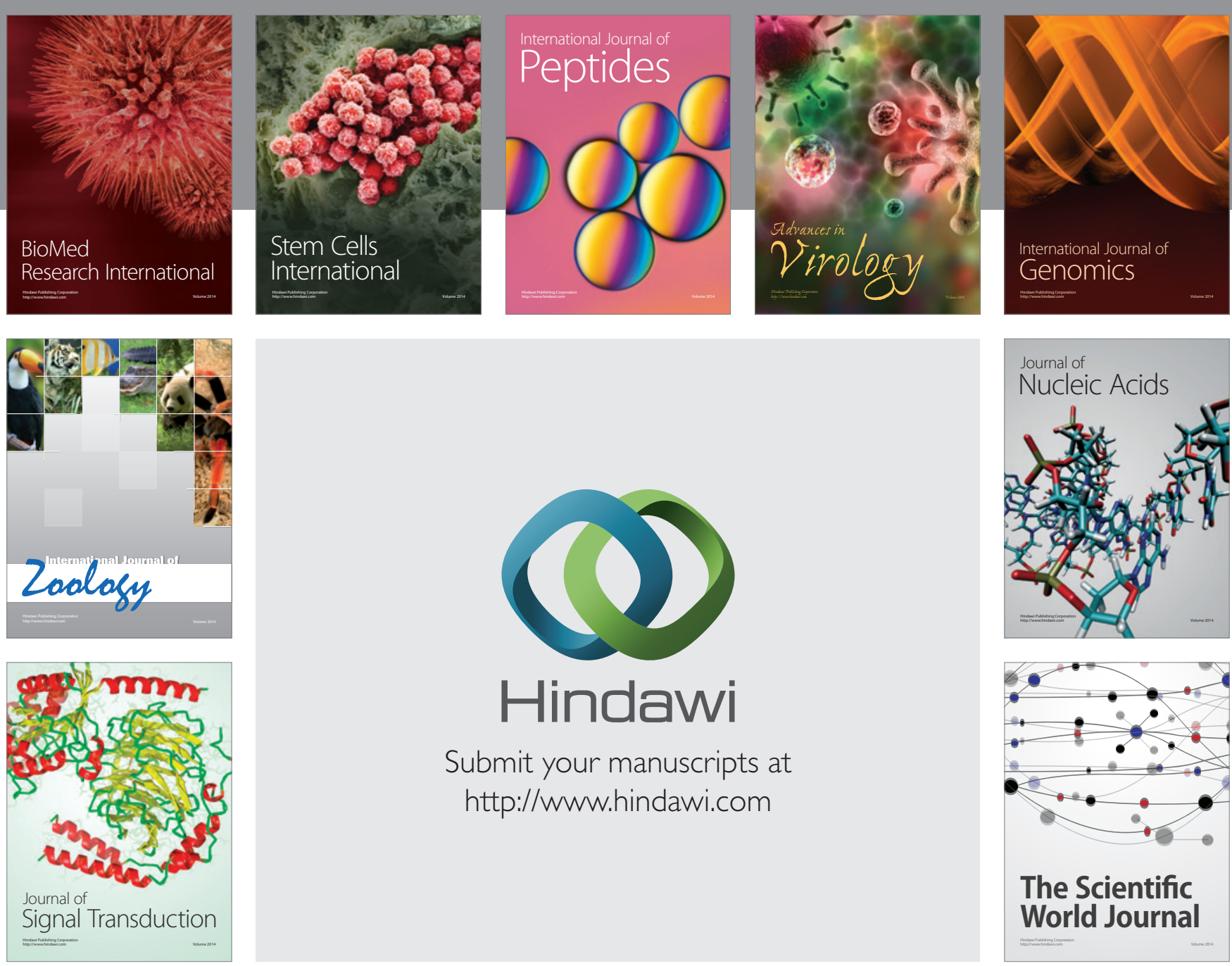

Submit your manuscripts at

http://www.hindawi.com
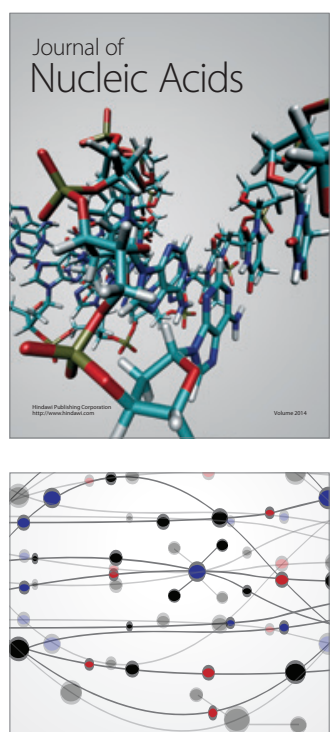

The Scientific World Journal
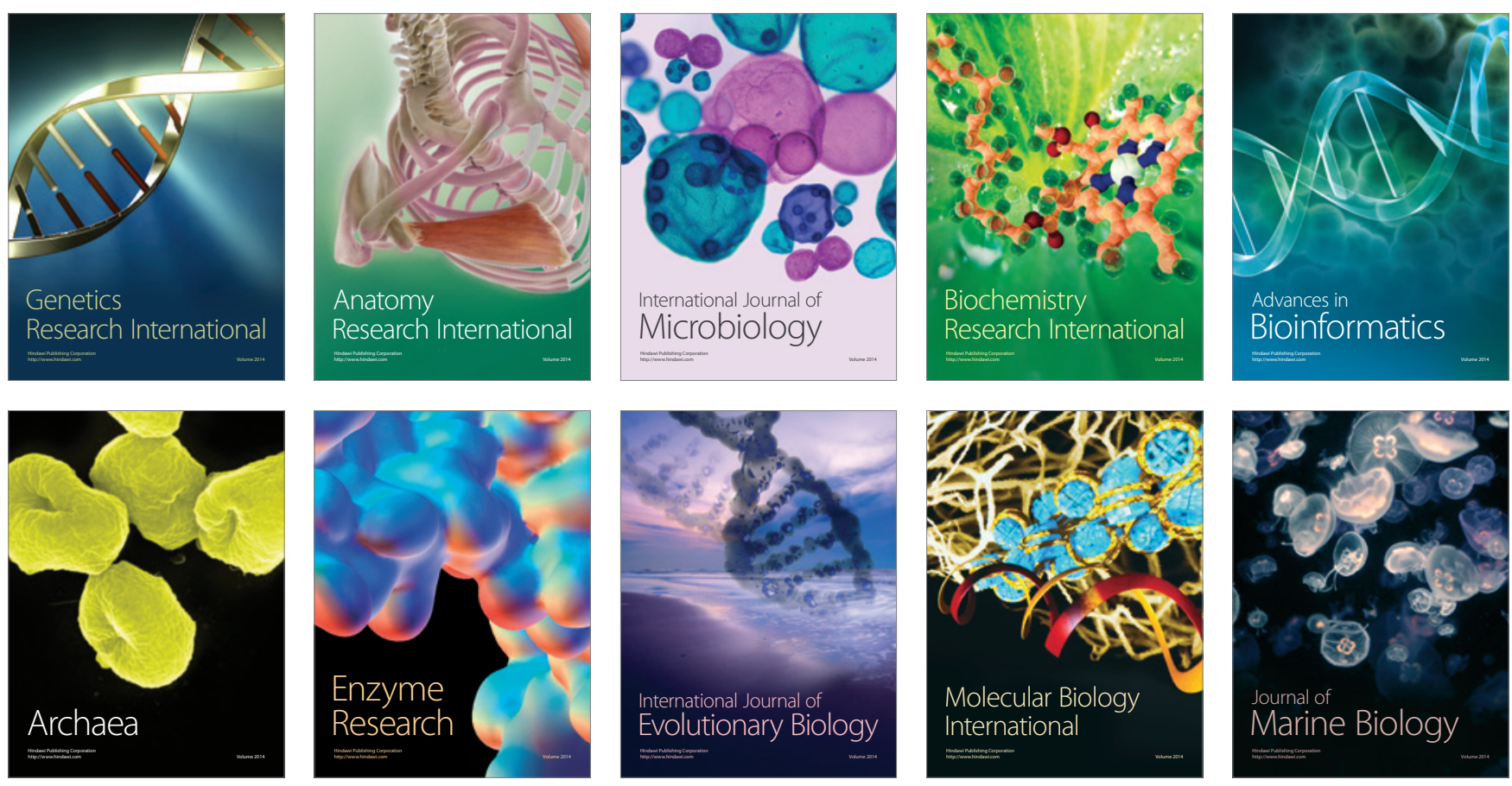